\author{
MACIEJ SKORY \\ ORCID: 0000-0002-1116-3169 \\ Uniwersytet Wrocławski \\ Instytut Prawa Cywilnego \\ Zakład Prawa Gospodarczego i Handlowego
}

\title{
CHARAKTER PRAWNY TAK ZWANEJ UMOWY DOWODOWEJ Z ART. $458^{9}$ K.P.C.
}

\begin{abstract}
Abstrakt: Celem artykułu jest analiza regulacji prawnej tak zwanej umowy dowodowej $\mathrm{z}$ art. $458^{9}$ k.p.c. jako instytucji nowej w polskiej regulacji postępowania sądowego w sprawach gospodarczych. Ten nowy typ umowy zestawiono z innymi znanymi prawu polskiemu tak zwanymi umowami procesowymi, wskazując odmienności przyjętej w tym wypadku konstrukcji prawnej. Podjęta została także próba oceny umowy dowodowej z uwzględnieniem reguł typologii umów, a także analiza konsekwencji procesowych, jakie mogą powstać przy stosowaniu tego rodzaju porozumień. Zwrócono także uwagę na możliwości praktycznego wykorzystania tej instytucji, zwłaszcza w kontekście ewentualnych nadużyć. W związku z tym w opracowaniu zostały także przedstawione rozważania poświęcone ewentualnym przyczynom i skutkom wadliwości umowy dowodowej.
\end{abstract}

Słowa kluczowe: umowa dowodowa, postępowanie cywilne, prawo gospodarcze, umowy procesowe, typologia umów

Funkcjonujący w Polsce system wymiaru sprawiedliwości bez wątpienia nie spełnia oczekiwań zarówno jego funkcjonariuszy, w tym sędziów, adwokatów i radców prawnych, jak i jego „klientów” — uczestników postępowań, którzy nie tylko zmagają się z wymogami formalnymi, ale przede wszystkim zmuszeni są długo oczekiwać na ostateczne rozstrzygnięcia ich spraw. Wskazywanie bolączek istniejącego systemu już dawno przestało mieć istotny walor praktyczny i coraz częściej staje się materią czysto publicystyczną, a nawet polityczną. Wyzwaniem współczesnych czasów nie jest zatem diagnozowanie sytuacji, o której powiedziano już dostatecznie dużo, ale przejście do działań i wprowadzenie rozwiązań, które pozwolą na rzeczywiste polepszenie działalności organów wymiaru sprawiedliwości. Wszyscy, którzy choć trochę znają realia, wiedzą, że w obliczu kryzysu sądownictwa mogą być podejmowane działania o charakterze merytorycznym, racjonalnym, obiektywnie uzasadnionym i spotykające się jeśli nie z powszechną aprobatą, to przynajmniej życzliwym przyjęciem przez zdecydowaną 
większość praktyków. Niestety, doświadczenie wskazuje także, iż kryzys może być pożywką dla wprowadzania rozwiązań populistycznych, pozornych, fasadowych, które być może prima facie dla osób niezaznajomionych z praktyką wydają się atrakcyjne, jednak w zderzeniu z realiami, przy chłodnym osądzie, okazują się nieefektywne bądź nawet szkodliwe. Narzekanie nie może być metodą neutralizowania frustracji społecznej. Dlatego próby naprawy obecnej sytuacji podejmowane przez różnego rodzaju instytucje trzeba pochwalać i absolutnie wspierać. Niemniej jednak nie należy bezkrytycznie podchodzić do wszelkich proponowanych zmian, gdyż nie tylko mogą one okazać się nieskuteczne, ale wręcz (w przypadku złej legislacji) pogłębiać zjawiska patologiczne. Krytyczna i obiektywna ocena wprowadzanych zmian ma fundamentalne znaczenie dla kształtowania zdrowego i efektywnego systemu prawnego. Warto także dodać, że nadmierna krytyka albo przesadny strach przed nowością lub zwykły oportunizm nie mogą prowadzić do kwestionowania rozwiązań pożytecznych, które nieraz z uwagi na ich nowatorski charakter mogą być w pierwszym etapie funkcjonowania trudne do akceptacji. Powszechne uznanie oraz docenienie rozwiązań w praktyce wymaga nieco czasu, ale skrócić go może - i powinna — dogłębna analiza doktrynalna reformowanych instytucji. Taką właśnie rolę we współczesnym świecie pełni między innymi nauka prawa. Celem niniejszego opracowania jest przyjrzenie się jednemu z rozwiązań, jakie proponuje ustawodawca w celu przyspieszenia i usprawnienia orzekania w sądach gospodarczych — tak zwanej umowie dowodowej, o której mowa w art. $458^{9}$ k.p.c. Rozwiązanie to bez wątpienia stanowi novum w polskim systemie prawa. Czy się sprawdzi - jest kwestią czasu. Wymaga jednak gruntownej analizy zarówno z punktu widzenia użyteczności, jak i zgodności z systemem prawnym, a także określenia jej miejsca w porządku prawnym. Wszystkie te działania służyć mają lepszemu zrozumieniu natury tego rodzaju umowy, wskazania jej zalet oraz wad, po to między innymi, aby ułatwić stronom zawieranie odpowiednich porozumień, a sądom dokonywanie ich trafnej oceny oraz właściwej kwalifikacji. Oczywiste jest, że tak określony cel badań nad umową dowodową jawi się jako zamierzenie niezwykle ambitne, które w ramach niniejszego — siłą rzeczy ograniczonego rozmiarami publikacji - opracowania nie może być w pełni zrealizowane. Niech zatem funkcją tego tekstu będzie zasygnalizowanie problemów oraz określenie pól do dalszej analizy omawianej instytucji, która zapewne będzie rozwijana i pogłębiana przez innych autorów.

Wskazane spostrzeżenia w swym zasadniczym trzonie mają charakter uniwersalny - dotyczą zmian we wszystkich obszarach prawa. Trudno przy tym wskazywać, że jedne z tych obszarów są ważniejsze, a inne charakteryzuje mniejszy ciężar gatunkowy. Wydaje się jednak, że w zakresie prawa gospodarczego wprowadzane zmiany mogą w stosunkowo szybkim czasie przynieść efekty zarówno pozytywne, jak i negatywne. Wynika to przede wszystkim stąd, że obrót gospodarczy na tle innych rodzajów obrotu, a w szczególności innych regulacji prawnych, wykazuje ogromną dynamikę. Przedsiębiorcy szybko reagują na wpro- 
wadzane zmiany, gdyż stanowią one dla nich albo sposobność do zwiększenia efektywności swoich przedsiębiorstw, albo wręcz przeciwnie - ich ograniczenie wymuszające konieczność dostosowania się i zmiany dotychczasowej praktyki działania. Dlatego zwłaszcza w obszarze prawa gospodarczego szybka weryfikacja - także na płaszczyźnie teoretyczno-doktrynalnej — wprowadzanych rozwiązań jest szczególnie ważnym zadaniem. W przypadku tak zwanych umów dowodowych pilna potrzeba określenia ich charakteru oraz cech umożliwiających właściwą kwalifikację oraz zastosowanie, także w interakcjach z innymi umowami (stosunkami), wynika $\mathrm{z}$ tego, że rozwiązanie to obejmuje zarówno obszar prawa materialnego, jak i procesowego. Jest to okoliczność nie bez znaczenia również z tego względu, że dokonanie rzetelnej analizy instytucji o tak określonych cechach wymaga spojrzenia $z$ dwóch perspektyw, które nieraz się kłócą. Nadto rzetelna analiza wymaga od jej autora biegłości zarówno w materii dotyczącej prawa umów, jak i procedury cywilnej, co wbrew pozorom wcale nie jest tak łatwe do pogodzenia. $Z$ tego między innymi powodu przeprowadzone rozważania mają być jedynie przyczynkiem do pogłębionych badań nad umowami dowodowymi.

Źródłem unormowania umowy dowodowej jest art. $458^{9}$ kodeksu postępowania cywilnego ${ }^{1}$. Przepis został wprowadzony w ramach wielkiej, bez wątpienia jednej z najdalej idących ${ }^{2}$ nowelizacji procedury cywilnej, dokonanej ustawą z dnia 4 lipca 2019 roku o zmianie ustawy - Kodeks postępowania cywilnego oraz niektórych innych ustaw (Dz.U. z 2019 r. poz. 1469), druk sejmowy nr 3137. Regulacja ma charakter zupełny $\mathrm{w}$ tym sensie, że poza wskazanym przepisem w innych jednostkach redakcyjnych nie definiuje się umowy dowodowej ani nie wskazuje jej cech. Jednocześnie warto podkreślić, że wykładnia systemowa wskazuje na konieczność stosowania tego przepisu w ramach postępowania gospodarczego, co, biorąc pod uwagę inne przepisy regulujące ten tryb procedowania, będzie miało w przyszłości istotne znaczenie - o czym szerzej w dalszej części opracowania. Przywołany artykuł składa się z siedmiu paragrafów ${ }^{3}$, przy czym

${ }^{1}$ Ustawa z dnia 23 kwietnia 1964 roku (tekst jedn. Dz.U. z dnia 19 lipca 2019 roku, Dz.U. z 2019 r. poz. 1460), dalej: k.p.c.

2 O doniosłości nowelizacji świadczy choćby fakt, że w jej wyniku został opublikowany tekst jednolity kodeksu, a wcześniej, w ciągu 55 lat obowiązywania, tego rodzaju zabiegów było zaledwie cztery.

3 „§ 1. Strony mogą się umówić o wyłączenie określonych dowodów w postępowaniu w sprawie z określonego stosunku prawnego powstałego na podstawie umowy (umowa dowodowa). § 2. Umowę dowodową zawiera się na piśmie pod rygorem nieważności albo ustnie przed sądem. W przypadku wątpliwości uważa się, że umowa późniejsza utrzymuje w mocy te postanowienia umowy wcześniejszej, które da się z nią pogodzić. § 3. Umowa dowodowa zawarta pod warunkiem lub z zastrzeżeniem terminu jest nieważna. § 4. Zarzut nieważności lub bezskuteczności umowy dowodowej można podnieść najpóźniej na posiedzeniu, na którym powołano się na tę umowę, a jeśli uczyniono to w piśmie procesowym - najpóźniej w następnym piśmie procesowym albo na najbliższym posiedzeniu. § 5. Objęcie umową dowodową dowodu przeprowadzonego przed sądem przed jej zawarciem nie pozbawia go mocy dowodowej. § 6. Sąd nie dopuści z urzędu dowodu wyłączonego umową dowodową. § 7. Fakty, które miałyby zostać wykazane dowodami wyłączonymi przez umowę dowodową, sąd 
pierwsze trzy dotyczą zagadnień materialnoprawnych, a pozostałe - kwestii procesowych. Zasadne zatem jest rozpoczęcie analizy od zbadania cech umowy oraz jej normatywnej konstrukcji, a następnie przejście do konsekwencji procesowych tak zbudowanego tworu.

Dokonując egzegezy analizowanych przepisów, w pierwszym rzędzie narzuca się stwierdzenie, iż umowa o której mowa w art. $458^{9}$ k.p.c., jest umową nazwaną. Nie powinno budzić wątpliwości, że $\S 1$ omawianego przepisu ma charakter definicyjny, skoro zgodnie z często stosowaną w polskim systemie prawnym praktyką legislacyjną znajdujące się na końcu zdania w nawiasie sformułowanie zwięźle określa nazwę dla zdefiniowanej instytucji. Wydaje się, że jest to wniosek oczywisty, jednak co do tak postawionej tezy mogą pojawić się wątpliwości. Otóż mimo nadania nazwy oraz wskazania przedmiotu porozumienia, które mogą zawrzeć strony, próżno w omawianym przepisie znaleźć essentialiae negotii powstałego stosunku. $Z$ drugiej strony, skoro efekt do jakiego ma prowadzić umowa, a także wynikające z dalszych przepisów (§ 4-7) konsekwencje jej zawarcia są jasne, to wydawać by się mogło, że mamy w tym przypadku do czynienia $\mathrm{z}$ umową nazwaną. Jak w takim razie oceniać brak określenia elementów przedmiotowo istotnych? Wydaje się, że kluczem do odpowiedzi na to pytanie jest posłużenie się przez prawodawcę słowem „umowa”. Zasadniczo ten termin stosowany jest w odniesieniu do instytucji prawa materialnego, choć oczywiście znane są także tak zwane umowy procesowe. Przykładem może być choćby umowa prerogacyjna, o której mowa w art. 46 k.p.c. ${ }^{4}$ Podobnie jak w przypadku umowy dowodowej wspomniany przepis rozpoczyna się słowami „Strony mogą umówić się $[\ldots]$., a w dalszej części opisuje efekt procesowy owego „umówienia”. Znaczenie obu instytucji wydaje się więc podobne, choć oczywiście występują różnice. Jedną z nich jest okoliczność, iż w odniesieniu do unormowania z art. 46 k.p.c. ustawodawca nie zdecydował się na użycie nazwy „umowa”. Owszem, w języku prawniczym, w odróżnieniu od języka prawnego, umowa taka występuje pod użytym tu już sformułowaniem ,umowa prerogacyjna”, niemniej fakt, że jest to pojęcie z zakresu języka prawniczego, w istotny sposób ogranicza możliwość stwierdzenia, że mamy w tym przypadku do czynienia $\mathrm{z}$ umową nazwaną $\mathrm{w}$ sensie normatywnym. Więcej nawet, wydaje się, że dla czystości językowej i przejrzystości komunikacyjnej w odniesieniu do tak zwanej umowy prerogacyjnej bardziej wskazane byłoby użycie słowa ,zapis”. Termin ten rozumiany jest bardziej jako postanowienie

może ustalić na podstawie twierdzeń stron, biorąc pod rozwagę całokształt okoliczności sprawy. Jeżeli ustalenia wymaga rozmiar należnego świadczenia, przepis art. 322 stosuje się".

4 „Art. $46 \S 1$. Strony mogą umówić się na piśmie o poddanie sądowi pierwszej instancji, który według ustawy nie jest miejscowo właściwy, sporu już wynikłego lub sporów mogących w przyszłości wyniknąć z oznaczonego stosunku prawnego. Sąd ten będzie wówczas wyłącznie właściwy, jeżeli strony nie postanowiły inaczej lub jeżeli powód nie złożył pozwu w elektronicznym postępowaniu upominawczym. Strony mogą również ograniczyć umową pisemną prawo wyboru powoda pomiędzy kilku sądami właściwymi dla takich sporów”. 
umowne, czyli element stosunku prawnego wynikającego z umowy o znacznie szerszym zakresie (albo odnoszącym się do innej umowy lub stosunku prawnego i ściśle z nimi powiązany), a nie samodzielny stosunek prawny. Typowym zastosowaniem tego pojęcia jest zbliżona instytucja, to jest "zapis na sąd polubowny” (uregulowana w art. $1161 \S 1$ k.p.c. ${ }^{5}$ ), która podobnie jak omawiana ma charakter procesowy, choć przecież jest zwykle częścią czynności materialnoprawnej. Trzeba w tym miejscu przypomnieć, że zgodnie ze wspomnianym we wstępie niniejszego opracowania zwyczajem, ustawodawca jednoznacznie zdefiniowal, a tym samym nazwał instytucję zapisu na sąd polubowny, umieszczając to sformułowanie w nawiasie, na końcu zdania opisującego jej cechy — praktyka z wszech miar godna aprobaty. Co jednak szczególnie ważne, ten sam prawodawca stwierdził, iż „verba legis - poddanie sporu pod rozstrzygnięcie sądu polubownego wymaga umowy stron [podkr. - M.S.]". Podsumowując, zapis na sąd polubowny nie jest umową, a do jego wprowadzenia konieczna jest umowa stron. Wniosek stąd może być tylko jeden - w tym przypadku, mówiąc o umowie stron, ustawodawca miał na myśli zgodne oświadczenie woli, a nie stosunek prawny, a już na pewno nie stosunek pod postacią umowy nazwanej ${ }^{6}$. Widać wyraźnie, że zupełnie inaczej uczynił w odniesieniu do umowy dowodowej.

Uwzględniając powyższe rozważania, nasuwa się pytanie, czy nie lepiej, aby wprowadzając do procedury cywilnej nową instytucję, prawodawca skorzystał ze stosowanych wcześniej w analogicznych sytuacjach znanych już i sprawdzonych rozwiązań, to jest nie używał żadnego określenia (art. 46 k.p.c.) lub użył bardziej neutralnego, jakim jest „,zapis” (art. $1161 \S 1$ k.p.c.). Skoro jednak racjonalny prawodawca zdecydował się na zastosowanie w tym przypadku innego rozwiązania, to należy zbadać, czy nie było ku temu jakiegoś istotnego powodu. Otóż poważniejsze zastanowienie się nad znaczeniem norm z art. $458^{9}$ k.p.c. każe przyjąć, że instytucja ta różni się od pozostałych i być może to właśnie było powodem nobilitowania jej do miana umowy, a nie postanowienia umownego (zapisu). O ile bowiem zastosowanie konstrukcji z art. 46 oraz 1161 k.p.c. w każdych warunkach prowadzi do tych samych skutków dla obu stron (obie będą występowały przed tym samym sądem/arbitrem, w ramach tej samej procedury), to w przypadku umowy dowodowej skutki te mogą być odmienne. Oczywiście, w pewnych granicach można wyobrazić sobie sytuację, w której to strony różnicują konsekwencje

5 „Art. $1161 \S 1$. Poddanie sporu pod rozstrzygnięcie sądu polubownego wymaga umowy stron, w której należy wskazać przedmiot sporu lub stosunek prawny, z którego spór wyniknął lub może wyniknąć (zapis na sąd polubowny)".

${ }^{6}$ Odnosząc się do terminologii oraz instrumentarium pojęciowego stosowanego w badaniu stosunków prawnych prawa prywatnego, należy przypomnieć, że słowo „umowa” może być używane i rozumiane w różny sposób, w zależności od kontekstu. Aby nadmiernie nie teoretyzować, w pewnym uproszczeniu można przyjąć, że nauka wyróżnia następujące rozumienia słowa umowa: a) czynność prawna — zgodne oświadczenie woli stron, b) stosunek cywilnoprawny, c) dokument lub dokumenty zawierające treści kształtujące stosunek prawny. 
prawne regulacji dotyczących właściwości sądu z uwagi na to, która z nich będzie powodem lub pozwanym, albo w jakim okresie klauzula będzie obowiązywała (na przykład właściwość sądu polubownego w okresie pierwszych dwóch lat obowiązywania umowy, a w latach późniejszych właściwość sądu powszechnego itp.), albo określić tę właściwość warunkowo (na przykład w sporach powyżej określonej kwoty właściwość sądu polubownego), niemniej jednak są to sytuacje niezwykle rzadkie, a i sama dopuszczalność takich rozwiązań jest podważana. Tak więc istnieje potencjalna przestrzeń do znacznego rozbudowywania klauzul właściwości sądu i tworzenia z nich konstrukcji na miarę wręcz umowy. Teza ta narzuca się tym bardziej, jeśli uświadomimy sobie, że w przypadku zapisu na sąd polubowny strony mogą określić złożone procedury prowadzenia postępowania, wyboru arbitrów, właściwości prawa, języka stosowanego przy rozstrzyganiu sporu itd. Co jednak kluczowe, we wszystkich tych przypadkach ostateczne konsekwencje zastosowania przyjętych rozwiązań będą $\mathrm{w}$ równym stopniu dotykały obu stron. Ta równoważność konsekwencji zapisów nie oznacza, iż dla obu stron określone rozwiązanie będzie równie korzystne czy równie uciążliwe. Przykładowo, wskazanie sądu właściwego — z uwagi na siedzibę jednej ze stron — będzie jej sprzyjało, a dla drugiej będzie pewną dolegliwością. Summa summarum jednak obie będą musiały dostosować się do przyjętej procedury wyboru arbitrów, obie będą musiały używać określonego języka arbitrażu oraz obie będą musiały stawić się w jednym (!) miejscu wyznaczonym do rozstrzygnięcia sprawy, które będzie właściwe do rozpoznania sprawy.

Z opisanych powodów, w przypadku regulacji dotyczących właściwości sądu, można wprawdzie wyobrazić sobie bardzo rozbudowane struktury umowne, jednak w praktyce sprowadzają się one do pojedynczego zapisu. W przypadku regulacji dotyczących zagadnień dowodowych rzecz się ma zgoła odmiennie. Można tu przewidzieć niezwykle nawet skomplikowane konstrukcje. Jest tu zatem pewne — dość szerokie zresztą — pole do negocjacji, kontraktowania oraz skorzystania z niemal całego spektrum instytucji prawa umów. W grę wchodzi bowiem możliwość doprecyzowania, jakiego rodzaju fakt można wykazywać określonymi środkami dowodowymi, w jakim terminie mogą być określone środki dowodowe stosowane, a nawet jakimi środkami może posługiwać się dana strona postępowania. Tym, co odróżnia umowę dowodową od wszelkich porozumień dotyczących właściwości organu rozstrzygającego, jest potencjalna asymetryczność rozwiązań. Owa asymetryczność niekoniecznie zresztą musi wynikać z określonych zapisów umownych, ale już z samej natury stosunku prawnego będącego źródłem sporu. Przykładowo w stosunkach, w których na skutek umowy dowodowej w istotny sposób zawężono katalog dostępnych stronom środków dowodowych, zdecydowanie poprawi się sytuacja tego z uczestników sporu, którego obowiązki (świadczenia) sprowadzały się do prostych aktywności. Wyobraźmy sobie spór dotyczący realizacji kompleksowej umowy o dzieło, w którego toku dopuszczono wyłącznie dowody z dokumentów urzędowych lub pochodzących od pod- 
miotów zaufania publicznego. Zamawiający w łatwy sposób wykaże, iż spełnił swoje świadczenie sprowadzające się de facto do zapłaty wynagrodzenia (wyciąg $\mathrm{z}$ rachunku bankowego/potwierdzenie przelewu). Tymczasem wykonawca będzie musiał wykazać, że dokonał szeregu czynności faktycznych i nieraz prawnych ${ }^{7}$, czego nie sposób udowodnić przewidzianymi w umowie środkami dowodowymi. Nadto wykonawca będzie musiał wskazać, w jakim zakresie zamawiający nie współdziałał przy realizacji umowy, co w tych warunkach procesowych (dowodowych) będzie równie niemożliwe. Opisana hipotetyczna sytuacja jest dobrą ilustracją niesymetryczności klauzul dowodowych, nawet gdy samo brzmienie postanowienia formalnie adresowane jest $\mathrm{w}$ równym stopniu do obu stron. Sprawia to, że w przypadku umów dowodowych pojawia się znaczne ryzyko nadużyć prowadzących do dysproporcji pozycji procesowej uczestników postępowania. Jak się zatem okazuje kluczem do zrozumienia wprowadzonej przez prawodawcę regulacji ograniczeń dowodowych jest uświadomienie sobie wpisanej w tę instytucje asymetryczności praw oraz wynikającej z niej implicite dysproporcji sytuacji procesowej, przede wszystkim z uwagi na naturalne zróżnicowanie ich pozycji w sferze stosunków materialnoprawnych.

Jak stwierdzono, naturalną konsekwencją umowy dowodowej jest dysproporcja sytuacji procesowej stron. Jest to stwierdzenie ważkie, być może nawet kontrowersyjne, które może być uznane za zbyt śmiałe czy radykalne. Jednocześnie można mu zarzucić oderwanie od konkretnej sytuacji, a więc nadmierne wyabstrahowanie. Argumentem za tak postawioną tezą byłaby okoliczność, że to, czy faktycznie tego rodzaju umowa prowadzi do dysproporcji, powinno być oceniane a casu ad casum. Problem jednak w tym, że konstrukcja przepisów nie pozwala na dokonanie obiektywnej oceny a casu ad casum właśnie, skoro mamy do czynienia $\mathrm{z}$ umową procesową i organ rozstrzygający związany jest jej postanowieniami w taki sposób, że zgodnie z $\S 6$ art. $458^{9}$ k.p.c. ,sąd nie dopuści z urzędu dowodu wyłączonego umową dowodową". Cóż zatem z tego, że teoretycznie wyobrażony tak zwany niezależny i obiektywny obserwator byłby w stanie stwierdzić, że zapisy umowy dowodowej prowadzą $\mathrm{w}$ danym przypadku do znacznego pogorszenia sytuacji procesowej strony (asymetryczności), skoro z powodów proceduralnych brakuje formuły, w ramach której można by to potwierdzić ${ }^{8}$. Egzemplifikacją tego problemu niech będzie sytuacja sędziego, któremu przedstawiono szereg dowodów wskazujących na konieczność uwzględnienia powództwa. Dowody te zostały

7 Przykładowo zawiadomienie określonych osób (na przykład sąsiadów o wykonywaniu pewnych prac), zawarcie określonych umów, dokonanie zgłoszeń do określonych jednostek (na przykład o zajęciu pasa drogowego) czy zawiadomień (na przykład Urzędu Dozoru Technicznego).

${ }^{8}$ Pewnym sposobem na zmniejszenie kategorycznego brzmienia omawianego rozwiązania jest $§ 7$, zgodnie z którym „fakty, które miałyby zostać wykazane dowodami wyłączonymi przez umowę dowodową, sąd może ustalić na podstawie twierdzeń stron, biorąc pod rozwagę całokształt okoliczności sprawy”. Problem jednak w tym, że twierdzenia stron niepoparte dowodami są gołosłowne, a sądowi trudno będzie w tym wypadku oprzeć na nich rozstrzygnięcie. 
szeroko omówione w pismach procesowych stron i dały podstawę do wyrobienia sobie przez sąd jednoznacznego stanowiska dotyczącego tego, jak powinno brzmieć słuszne i sprawiedliwe orzeczenie w danej sprawie. Cóż z tego jednak, jeśli okazało się, że na skutek zawartej umowy dowodowej gros z przedstawionych dowodów nie mogło być uwzględnionych, co doprowadziło do konieczności wydania odmiennego orzeczenia i oddalenia powództwa, które nie daje się pogodzić z poczuciem sprawiedliwości.

Przeprowadzone dotychczas rozważania potwierdzone opisaną przykładową sytuacją sędziego rozstrzygającego spór gospodarczy pozwalają na sformułowanie tezy wynikającej z samej idei wprowadzenia ograniczeń dowodowych w systemie wymiaru sprawiedliwości. Teza ta sprowadza się do stwierdzenia, że polski prawodawca w przypadku postępowań gospodarczych zdecydował się odejść od prawdy materialnej jako podstawy orzekania i wprowadzić do polskiego systemu elementy formalnej teorii dowodowej. Wprawdzie zjawisko formalizowania obrotu, a także reguł postępowania sądowego jest obecne w naszej rzeczywistości i proces ten stale się rozwija, niemniej jednak dotychczas w tak newralgicznym obszarze oraz w takim nasileniu nie występował. Zdaje się, że ustawodawca zdecydował, iż lekiem na zdiagnozowane bolączki orzecznictwa sądowego w sprawach gospodarczych będzie danie stronom szansy na zawarcie umów dowodowych służących uproszczeniu postępowania, a to z kolei prowadzić będzie do przyspieszenia orzekania. Za zasadnością tego rozwiązania przemawia fakt, iż decyzję o zawarciu i przede wszystkim treści umowy dowodowej podejmują przedsiębiorcy, a więc podmioty profesjonalne. W tego rodzaju relacjach z uwagi na konieczność przyspieszenia obrotu oraz jego uproszczenia wprowadza się nieraz rozwiązania, które w innych przypadkach prowadziłyby do naruszenia praw uczestników obrotu. Rodzi się jednak pytanie, czy wyłom, jaki uczynił prawodawca w tym przypadku, nie jest zbyt daleko idący. Zapewne będzie to jeszcze przedmiotem wielu analiz oraz dyskusji, niemniej prima facie wydaje się, że kosztem teoretycznie szybszego i prostszego niż dotychczas postępowania w sprawach gospodarczych może być dopuszczenie do funkcjonowania w obrocie orzeczeń, których nie da się pogodzić z zasadami sprawiedliwości. Przeciwnicy tej tezy mogą wskazywać, że przecież także w ramach arbitrażu strony mają daleko idącą swobodę kształtowania reguł postępowania - w tym zarówno wybierania arbitrów, jak i wiążącej ich procedury. Ta ostatnia może z kolei przewidywać jeszcze dalej idące ograniczenia dowodowe (przykładem mogą być tak zwane arbitraże elektroniczne), które również mogą prowadzić do prymatu prawdy formalnej nad materialną oraz — w konsekwencji — do wadliwych orzeczeń. Jednak w przypadku arbitrażu istnieje instytucja, której zadaniem jest takie nieprawidłowości eliminować — skarga na orzeczenie sądu arbitrażowego regulowana art. 1205 i nast. k.p.c. W art. $1206 \S 2$ k.p.c. jako podstawę skargi wskazuje się tak zwaną klauzulę porządku publicznego, to jest stan, gdy wyrok sądu polubownego jest sprzeczny z podstawowymi zasadami porządku prawnego Rzeczypospolitej Polskiej. Istnie- 
je zatem instytucjonalna forma ochrony przed nieprawidłowościami, której nie przewidziano $\mathrm{w}$ razie orzekania przez sąd powszechny związany wyłączeniami dowodowymi określonymi przez strony. Problem ten może być tym bardziej dolegliwy, że przecież wbrew formułowanej w teorii prawa handlowego zasadzie równości stron stosunków handlowych oraz profesjonalizmowi jego uczestników praktyka życia gospodarczego pokazuje, że wielkie podmioty, o potężnej przewadze kontraktowej, wymuszają w relacjach z kontrahentami wprowadzanie takich postanowień umownych, które poprawiają ich sytuację prawną w sposób naruszający dobre obyczaje oraz zasady uczciwego obrotu ${ }^{9}$. Istnieje obawa, że ten sam mechanizm przewagi kontraktowej zostanie wykorzystany w celu wymuszania na kontrahentach niekorzystnych umów dowodowych.

Przeprowadzone dotychczas rozważania nad charakterem umowy dowodowej z art. $458^{9}$ k.p.c. pozwoliły na stwierdzenie, że jest to rodzaj umowy nazwanej o charakterze procesowym, istotnie różniącym się jednak od innego rodzaju umów procesowych ${ }^{10}$. Z faktu, iż mamy w tym wypadku do czynienia z umową, wynika kilka wniosków. Przede wszystkim, tak jak to ma miejsce w przypadku innych umów, do wprowadzenia ograniczeń dowodowych konieczna jest zgoda obu stron. Po drugie, tak jak w przypadku innych umów, umowa dowodowa może być częścią (elementem) innego stosunku prawnego i wraz z nim tworzyć umowę mieszaną czy nienazwaną. A zatem do zawarcia umowy dowodowej może dojść w powszechnie stosowanych trybach, byleby w zgodzie z wymogami art. $458^{9} \S 2$ k.p.c., zgodnie z którym „umowę dowodową zawiera się na piśmie pod rygorem nieważności albo ustnie przed sądem. W przypadku wątpliwości uważa się, że umowa późniejsza utrzymuje w mocy te postanowienia umowy wcześniejszej, które da się z nią pogodzić". Nadto uwzględniając treść art. $458^{9} \S \S 3$ i 4 k.p.c.,

umowa dowodowa zawarta pod warunkiem lub z zastrzeżeniem terminu jest nieważna, zaś zarzut nieważności lub bezskuteczności umowy dowodowej można podnieść najpóźniej na posiedzeniu, na którym powołano się na tę umowę, a jeśli uczyniono to w piśmie procesowym — najpóźniej w następnym piśmie procesowym albo na najbliższym posiedzeniu.

Ponieważ przytoczone przepisy wyczerpują całość regulacji materialnoprawnej umowy przewidzianej przez prawodawcę, należy przyjąć, że w pozostałym zakresie podlega ona takim samym zasadom jak inne umowy. Zdanie to jest prawdziwe z tym zastrzeżeniem, że mamy do czynienia z umową procesową, a zatem stosowanie do niej pełnego instrumentarium wykorzystywanego przy analizie

9 Przykłady można by mnożyć. Najbardziej charakterystyczne przez wiele lat było nadmierne wydłużanie terminów zapłaty. Pewnego rodzaju remedium na tę patologiczną sytuację wprowadziła dopiero ustawa o terminach zapłaty.

${ }^{10}$ Na temat definicji umów procesowych wypowiedzieli się F.K. Fierich i E. Waśkowski. Zdaniem F.K. Fiericha umowy procesowe to zgodne objawienie woli stron wiodących spór, w granicach prawnie dozwolonych, celem wywołania pewnego skutku procesowego. Według E. Waśkowskiego umowy procesowe to porozumienia stron mające na celu wywołanie skutków procesowych. Podaję za: R. Kulski, Umowy procesowe w postępowaniu cywilnym, Kraków 2006. 
umów cywilnoprawnych wymaga ostrożności ${ }^{11}$. Ściślej rzecz biorąc, pewne przepisy mogą być w tym wypadku stosowane mutatis mutandis, a inne w ogóle nie będą mieć zastosowania. Podobnie zresztą rzecz się ma w odniesieniu do kategorii, którymi posługuje się nauka prawa przy typizowaniu umów. Jak zawsze w tego rodzaju przypadkach trudność polega na wskazaniu, które przepisy czy rozwiązania mają zastosowanie do omawianej umowy, które nie mają zastosowania, a które stosuje się w postaci zmodyfikowanej. Bez wątpienia umowa dowodowa nie może być oceniana na podstawie niektórych cech typologicznych. Umowa ta nie określa świadczeń stron, a więc nie należy doszukiwać się w niej cech umów zobowiązujących czy rozporządzających, z oczywistych względów nie jest to umowa ani jednostronnie, ani dwustronnie zobowiązująca. Nie sposób także mówić o wzajemnym charakterze umowy, ten jest bowiem warunkowany relacją do ut des, kiedy to świadczenie jednej ze stron jest motywowane świadczeniem drugiej. Równie chybione jest stosowanie innych wyróżników — nie mamy tu do czynienia z umową odpłatną czy nieodpłatną, przysparzającą ani losową. Wydaje się, że z uwagi na brak świadczenia nie można tej umowy zakwalifikować jako abstrakcyjnej, ale jednocześnie zgodzić się wypada, że dochodzi do skutku solo consesu, czyli jest konsensualna. Z kolei biorąc pod uwagę charakter podmiotów, które mogą zawrzeć analizowany rodzaj umowy, jest to umowa dwustronnie gospodarcza, na co wskazują wyniki wykładni systemowej. Na marginesie warto zastanowić się, jak należałoby oceniać sytuację, gdyby umowę dowodową zawarły strony niebędące przedsiębiorcami albo utraciły taki status. Jest to jednak temat na odrębne opracowanie.

W prawie kontraktów wyróżnia się umowy swobodnie negocjowane i adhezyjne. Nie budzi wątpliwości, że umowa dowodowa może być zawarta w ramach negocjacji, jak się nawet wydaje — z uwagi na jej znaczenie — jest to tryb zdecydowanie preferowany. Nie wyklucza to wszakże przystąpienia do umowy, a więc skorzystania z tak zwanej adhezji. Ważne, aby owo przystąpienie zostało dokonane skutecznie. Wspomniany już § 2 statuuje obowiązek zawarcia umowy „na piśmie pod rygorem nieważności albo ustnie przed sądem". Raczej trudno sobie wyobrazić, aby zawarcie umowy ustnie przed sądem dokonało się w trybie adhezji, jednak zawarcie w formie pisemnej na podstawie wzorca przygotowanego wcześniej przez proponenta spełniłoby wymogi ustawy. Wymóg formy pisemnej (w dodatku pod rygorem nieważności) świadczy o znaczeniu, jakie prawodawca nadaje omawianej instytucji. Umowa dowodowa nie może być zatem zawarta w coraz bardziej popularnej i powszechnie stosowanej w obrocie formie dokumentowej, o której mowa w art. $77^{3}$ kodeksu cywilnego, a tym bardziej w sposób konkludent-

11 Skoro jednak prawodawca zdecydował się nazwać tę umowę oraz (choćby częściowo) uregulować zagadnienia materialnoprawne (choć w przepisach procedury cywilnej), to można pokusić się o jej analizę także przy uwzględnieniu dorobku doktryny prawa materialnego. Więcej o różnicach pomiędzy umowami cywilnoprawnymi a tak zwanymi umowami procesowymi w R. Kulski, op. cit. 
ny. Jednak w przypadku konieczności porozumiewania się na odległość istnieje możliwość skutecznego zawarcia umowy albo przystąpienia do niej, jeśli nastąpi to $\mathrm{w}$ kwalifikowanej formie elektronicznej, albowiem zgodnie $\mathrm{z}$ art. $78 \S 2$ k.c. „oświadczenie woli złożone w formie elektronicznej jest równoważne z oświadczeniem woli złożonym w formie pisemnej”. Jak już zaznaczono, umowa dowodowa z technicznego punktu widzenia może być częścią innego stosunku prawnego i tak zapewne w większości przypadków będzie, gdyż bez wątpienia ma ona charakter akcesoryjny, służebny względem głównych zobowiązań stron. Rodzi się w tym wypadku wątpliwość, czy skuteczne będzie zawarcie umowy dowodowej, gdy jej postanowienia zostaną objęte wzorcem umownym stanowiącym załącznik do umowy głównej zawartej w formie pisemnej. Powszechnie stosowane wzorce umowne i regulaminy zawierają często zapisy wypełniające znamiona tak zwanych umów procesowych - dotyczy to zarówno zapisów na sąd polubowny, jak i umów prerogacyjnych. $\mathrm{O}$ ile w przypadku tych drugich dopuszczalność tej formy nie budziła wątpliwości, o tyle w przypadku umów o arbitraż poglądy doktryny nie były jednolite, a to przede wszystkim z uwagi na obowiązujące Polskę normy prawa międzynarodowego ${ }^{12}$. Wracając do kwestii umów dowodowych, jeżeli będą one stanowiły „umowę w umowie”, to wydaje się, że powinny dzielić los prawny tej pierwszej (głównej) i — jeśli została ona zawarta w formie pisemnej — można bronić stanowiska, że kwalifikacja ta powinna rozciągać się także na umowę dowodową, choćby jej postanowienia zawarte były w dołączonym wzorcu umownym. Jak inaczej oceniać bowiem tę sytuację, gdyby przykładowo główne ograniczenia dowodowe znalazły się w umowie (dokumencie) podpisanym, a pozostałe we wzorcu umownym. Czy te ostatnie nie byłyby wówczas wiążące, a umowa obowiązywała tylko w połowie? Jednocześnie wzgląd na wagę regulacji oraz dalekosiężne konsekwencje umowy dowodowej nakazywałyby oczekiwać, że strony zawierające tego rodzaju porozumienie, choćby w ramach innej umowy, złożyły swoje oświadczenia w sposób niebudzący jakichkolwiek wątpliwości co do ich intencji oraz zapewniając świadomość stron w zakresie reżimu, jakiemu będą polegać ich ewentualne spory. Nie wiadomo, jak w tym przypadku ostatecznie ukształtuje się praktyka.

$\mathrm{Na}$ koniec rozważań poświęconych konsekwencjom uznania regulacji $\mathrm{z}$ art. $458^{9}$ k.p.c. za stosunek umowny podkreślić trzeba, że dla tej umowy będą miały wprost zastosowanie przepisy regulujące różnego rodzaju wadliwości oświadczeń woli. A zatem umowa dowodowa może być dotknięta nieważnością w przypadku braku świadomości lub swobody (art. 82 k.c.), błędu (art. 84 k.c.), podstępu (art. 86 k.c.), groźby (art. 87 k.c.) lub pozorności (art. 83 k.c.) ${ }^{13}$. Warto

12 Przede wszystkim tak zwana konwencja nowojorska - konwencja o uznawaniu i wykonywaniu zagranicznych orzeczeń arbitrażowych z dnia 10 czerwca 1958 roku.

13 Wśród wadliwości często wymienia się także wyzysk. Jednak w kontekście umów dowodowych raczej nie będzie miał on zastosowania, gdyż dotyczy umów zobowiązaniowych, których przedmiotem są świadczenia, omawiana zaś umowa dowodowa — jak już stwierdzono — nie kwalifikuje się do tej kategorii. 
nieco słów poświęcić jednak temu ostatniemu przypadkowi. Trudno wyobrazić sobie, aby strony zawarły samoistną umowę dowodową dla pozoru (co innego, gdy taka umowa byłaby częścią innej umowy dotkniętej nieważnością — wówczas, co oczywiste, dzieli los tej pierwszej). Natomiast znacznie łatwiej wyobrazić sobie zawarcie umowy dowodowej po to, aby jedynie doprowadzić do procesu sądowego, w ramach którego sąd, uwzględniając ograniczenia dowodowe, byłby zmuszony - wbrew faktom - wydać określone orzeczenie, a tym samym usankcjonować stan, którego w innych warunkach strony nie mogłyby osiągnąć, gdyż czynność prawna mogłaby zostać uznana za nieważną. Zważyć trzeba, że w ramach tak prowadzonego postępowania sąd nie miałby możliwości przeciwdziałać osiągnięciu określonego efektu (na przykład transferu znacznych środków na rzecz innego podmiotu), nieraz przestępczemu (tak zwany drenaż spółki albo spłacanie tylko niektórych wierzycieli). W innych przypadkach, na przykład ugody sądowej albo cofnięcia pozwu zgodnie z art. 203 § 4 k.p.c. ${ }^{14}$, sąd ma możliwość przeciwdziałania instrumentalnemu wykorzystaniu instytucji wymiaru sprawiedliwości, tu natomiast ( $\mathrm{z}$ uwagi na przywołane wcześniej bezwzględne brzmienie art. $458^{9}$ $\S 6$ k.p.c.) możliwości takiej nie ma. Była już zresztą mowa na temat ryzyka wydawania orzeczeń niedających się pogodzić z poczuciem sprawiedliwości.

$\mathrm{Z}$ innych zagadnień dotyczących wadliwości czynności prawnej w kontekście umów dowodowych wymienić trzeba abuzywność, o której mowa w art. $385^{1}$ k.c. Wprawdzie przepis ten dotyczy stosunków konsumenckich, a umowy dowodowe zawierane są między przedsiębiorcami, jednak podkreślić trzeba, że zgodnie z nowelizacją kodeksu cywilnego tak zwany przedsiębiorca jednoosobowy w stosunkach z innymi przedsiębiorcami będzie traktowany jak konsument $\mathrm{w}$ zakresie stosowania przepisów o klauzulach abuzywnych ${ }^{15}$. Oznacza to, że umowy dowodowe lub nawet niektóre ich postanowienia mogą być oceniane przez pryzmat kształtowania praw i obowiązków w sposób sprzeczny z dobrymi obyczajami, rażąco naruszając interesy przedsiębiorcy jednoosobowego, o ile oczywiście nie były indywidualnie uzgodnione. $Z$ uwagi na tak zwaną abstrakcyjną kontrolę wzorców umownych oraz prowadzony przez Prezesa UOKIK rejestr klauzul abuzywnych można się liczyć z wpisaniem wielu postanowień umów dowodowych do tego rejestru, a tym samym wyeliminowaniem ich z obrotu. Być może jest to częściowe remedium na ograniczenie ryzyka narzucania niekorzystnych umów dowodowych przez podmioty o dużej sile kontraktowej. Co jednak, jeżeli dany przedsiębiorca zechce zakwestiono-

14 „Art. 203 § 4. Sąd może uznać za niedopuszczalne cofnięcie pozwu, zrzeczenie się lub ograniczenie roszczenia tylko wtedy, gdy okoliczności sprawy wskazują, że wymienione czynności są sprzeczne z prawem lub zasadami współżycia społecznego albo zmierzają do obejścia prawa".

15 Art. $385^{5}$. Przepisy dotyczące konsumenta zawarte w art. $385^{1}-385^{3}$ stosuje się do osoby fizycznej zawierającej umowę bezpośrednio związaną z jej działalnością gospodarczą, gdy z treści tej umowy wynika, że nie ma ona dla niej charakteru zawodowego, wynikającego w szczególności z przedmiotu wykonywanej przez nią działalności gospodarczej, udostępnionego na podstawie przepisów o Centralnej Ewidencji i Informacji o Działalności Gospodarczej. 
wać umowę dowodową, która nie jest wpisana do rejestru postanowień umownych uznanych za niedozwolone. Wydaje się, że będzie mógł wówczas w postępowaniu sądowym wykazywać spełnienie przesłanek abuzywności. Problem jednak w tym, że arsenał środków dowodowych, z jakich będzie mógł skorzystać, może być w tym przypadku mocno ograniczony właśnie przez związanie sądu umową dowodową (art $458^{9} \S 6$ k.p.c.). Powstaje zatem sytuacja klinczu sprowadzająca się do szczególnego rodzaju sprzężenia zwrotnego związana z onus probandi - strona musi wykazać przesłanki abuzywności umowy dowodowej, ale nie może tego uczynić, gdyż umowa dowodowa zakazuje powoływania dowodów, które mogłyby wykazać jej abuzywność ${ }^{16}$. Biorąc pod uwagę wskazaną wątpliwość, trzeba rozważyć jeszcze treść art. $458^{9} \S 4$ k.p.c., zgodnie z którym „zarzut nieważności lub bezskuteczności umowy dowodowej można podnieść najpóźniej na posiedzeniu, na którym powołano się na tę umowę, a jeśli uczyniono to w piśmie procesowym — najpóźniej w następnym piśmie procesowym albo na najbliższym posiedzeniu". Wydaje się zatem, że procedowanie z uwzględnieniem ograniczeń dowodowych może poprzedzić w ramach tego postępowania zbadanie skuteczności owych ograniczeń bez konieczności ich respektowania już na tym wstępnym etapie. Gdyby prawodawca nie dopuścił do takiej możliwości, sytuacja klinczu stanowiłaby istotny problem. $\mathrm{Z}$ teoretycznego punktu widzenia istniałaby oczywiście możliwość uprzedniego wytoczenia powództwa na podstawie art. 189 k.p.c. w celu ustalenia istnienia stosunku prawnego lub jego treści w zakresie reguł dowodowych. Można jednak wyrazić obawę, czy sądy dopuściłyby tego rodzaju postępowanie, uznając, że stronie przysługuje interes prawny (gravamen).

Dla wskazanych sytuacji jest dodatkowe rozwiązanie. Otóż zgodnie z treścią art. $458^{6} \S 1$ k.p.c. „na wniosek strony, która nie jest przedsiębiorcą lub jest przedsiębiorcą będącym osobą fizyczną, sąd rozpoznaje sprawę z pominięciem przepisów niniejszego działu ${ }^{17}$ ". Oznacza to, że w celu uniknięcia ryzyk związanych z ograniczeniami dowodowymi strony w łatwy sposób mogą „zneutralizować” postanowienia umowy dowodowej. Być może zatem jest to przewidziane przez prawodawcę remedium na wskazane w niniejszym opracowaniu wątpliwości dotyczące analizowanej instytucji, włączając $\mathrm{w}$ to również jeden $\mathrm{z}$ najpoważniejszych, mianowicie istotne odejście od zasady prawdy materialnej. Jeżeli strony akceptują procedowanie sprawy w trybie gospodarczym, to tym samym godzą się na zastosowanie ograniczeń dowodowych przewidzianych w zawartej przez nie umowie, wszak volenti non fit iniuria. Trudno ocenić, czy faktycznie zamiarem prawodawcy było dopuszczenie tak łatwego sposobu na zignorowanie wiążących

16 Podobna zresztą, choć nie identyczna sytuacja będzie miała miejsce w przypadku powoływania się w procesie przez którąś ze stron na nieważność umowy zobowiązaniowej, która to umowa obejmowałaby także nieważność jej postanowień odnoszących się do ograniczeń dowodowych.

17 Zgodnie z $§ 2$ tego przepisu: „Wniosek, o którym mowa w $\S 1$, strona może złożyć w terminie tygodnia od dnia doręczenia jej na piśmie pouczeń, o których mowa w art. $458^{4} \S 1$, a jeżeli doręczenie pouczeń nie było wymagane — w pozwie albo pierwszym piśmie procesowym pozwanego". 
stron zapisów umowy dowodowej. Jeśli by tak było, wówczas działanie choćby jednej ze stron pozbawiałoby drugą możliwości pełnej eksploatacji treści wiążącego strony stosunku prawnego. Rozwiązanie takie mocno ingerowałoby w zasadę pacta sunt servanda, która jednak w ostatnich czasach doznaje coraz większych ograniczeń na bardzo różnych płaszczyznach. W obliczu wskazanych wątpliwości trudno jednoznacznie wypowiedzieć się, jakie były zamiary prawodawcy oraz jak ukształtuje się ostatecznie praktyka stosowania omawianych przepisów.

Kończąc rozważania poświęcone charakterowi umowy z art. $458^{9}$, nieco wychodząc poza ściśle zakreślony zakres tematyczny wyznaczony tytułem niniejszego opracowania, warto zwrócić uwagę na wątpliwości dotyczące treści poszczególnych postanowień umowy dowodowej. Jak wspomniano, prawodawca nie pokusił się o doprecyzowanie zawartości umowy, co — jak się wydaje — należy interpretować jako pozostawienie stronom swobody w kształtowaniu tego rodzaju umów i uszanowanie ich autonomii. A zatem zgodnie z zasadą swobody umów ograniczenia w kształtowaniu treści umowy dowodowej zgodnie z art. $353^{1}$ k.c. może stanowić sprzeczność z właściwością (naturą) stosunku, zasadami współżycia społecznego lub ustawą. Jak wspomniano, ten ostatni przypadek zasadniczo nie będzie występował, gdyż prawodawca pozostawił stronom wolną rękę. Zasady współżycia społecznego mające znaczenie dla oceny umowy dowodowej zapewne będą jeszcze przedmiotem analiz i zostaną wskazane w praktyce orzeczniczej, dlatego najbardziej interesujące na obecnym etapie obowiązywania przepisów może być zbadanie natury stosunku. Oczywiście pod warunkiem, że w przypadku umowy procesowej można w ogóle mówić o stosunku prawnym. Niemniej umowę dowodową można także rozpatrywać jako część umowy regulującej określony stosunek zobowiązaniowy (jak ustalono we wstępie — ma przecież charakter służebny względem stosunku materialnoprawnego) i w tym właśnie kontekście rozpatrywać zgodność jej postanowień. Uwzględniając poczynione zastrzeżenia, bardzo trudno jest in abstracto ocenić naturę umowy dowodowej, a tym bardziej postanowienia, które byłyby z nią sprzeczne. Ujmując rzecz grosso modo, można jednak sformułować kilka uwag. Po pierwsze, ostrożnie można prezentować tezę, że mimo iż umowa dowodowa nie może być zawarta pod warunkiem lub z zastrzeżeniem terminu (art. $458^{9} \S 3$ ), to poszczególne jej postanowienia mogą być uzależnione od pewnych zdarzeń lub upływu czasu, na przykład do określonego momentu (etapu) pewne dowody mogą być dopuszczone, a później już nie (choćby z uwagi na naturę okoliczności mających być wykazanymi — przykładowo tak zwane roboty zanikowe w procesie budowlanym). Ponadto wydaje się, że nic nie stoi na przeszkodzie, aby, co do zasady, dopuścić różne reguły dowodowe dla każdej ze stron. Przede wszystkim dlatego, że zwykle mają one interes w wykazywaniu bardzo rożnych okoliczności, a więc nawet gdyby reguły były formalnie tożsame dla wszystkich, faktycznie uderzałyby w jedną ze stron. Była już zresztą o tym mowa. Ponadto strony mogą przecież w procesie kontraktowania negocjować w sposób uwzględniający ich sytuację faktyczną i godzić się na pewne ograniczenia, rów- 
noważąc ryzyka z tym związane przez wprowadzanie ograniczeń innego rodzaju dla drugiej strony ${ }^{18}$. W tym kontekście ciekawe byłoby także ograniczenie dotyczące zakazu powoływania biegłych albo nawet biegłych określonych specjalności (jak szczegółowo określonej?), a także możliwości obchodzenia tego zakazu poprzez formułowanie tez oraz zadawanie biegłemu pytań wykraczających poza jego specjalność. Wątpliwość budzi także kwestia objęcia umową dowodową wykazywania pewnych okoliczności czy też wyłącznie posługiwania się określonymi środkami dowodowymi (wprowadzenie tych ostatnich może de facto prowadzić do wyłączenia wykazywania faktów określonego rodzaju). Interesujące byłoby także dopuszczenie wyłączenia dowodu z przesłuchania stron albo tylko jednej strony. Ilość stanów faktycznych i potencjalnych rozwiązań, a także wielości ocen jest w tym wypadku ogromna $\mathrm{i}$ - jak zaznaczono - na pewno stanowić będzie bardzo interesujący przedmiot badań, a nieraz istotny problem orzeczniczy.

Podsumowując przeprowadzoną $\mathrm{w}$ niniejszej pracy analizę, można stwierdzić, że tak zwana umowa dowodowa jest instytucją nieznaną dotychczasowemu prawu polskiemu, bardzo skąpo uregulowaną, bez wątpienia kwalifikowaną jako umowa nazwana o charakterze procesowym, jednak jej cechy, w tym przede wszystkim wynikająca z natury asymetryczność, funkcja oraz istotna ingerencja w stosowane dotychczas zasady orzekania, mogą stanowić źródło problemów oraz bardzo różnorodnych ocen. Są to czynniki nakazujące przyglądać się tej instytucji z dużą uwagą i jednocześnie stosować z ostrożnością.

\section{THE LEGAL NATURE OF A SO-CALLED EVIDENCE AGREEMENT DESCRIBED IN ART. $458^{9}$ OF THE CIVIL PROCEDURE CODE}

Summary

The aim of the article is the analysis of the so-called evidence agreement described in Art. 4589 of the Civil Procedure Code, which is the new regulation in the Polish civil procedure in economic affairs. This new type of agreement has been compared to other known Polish law so-called procedural agreements, showing differences of this type of legal construction. There has also been an attempt toevaluate the evidence agreement with regard to the rules of contract typology, as well as analysis of procedural consequences that can arise from the execution of these agree-

18 O możliwości nadużyć w tym zakresie i narzucania rozwiązań niekorzystnych dla słabszych graczy rynkowych — vide supra. 
ments. The possibilities of practical use of this legal institution has been also pointed out, especially in the context of possible abuses. In this context the deliberations dedicated possible causes and effects of evidence contract have also been included in this elaboration.

Keywords: evidence agreement, civil procedure, economic law, procedural agreements, contract typology

\section{BIBLIOGRAFIA}

Kulski R., Umowy procesowe w postępowaniu cywilnym, Kraków 2006. 